\title{
Detection of Bovine Herpesvirus-1 Infection in Bovine Clinical Samples by Direct Fluorescent Antibody Test
}

\author{
Dharmesh R. Patel*, Irsadullakhan H. Kalyani, Bhavesh J. Trangadia, \\ Kishan K. Sharma, Pushpa M. Makwana, Dhruv Desai, \\ Dushyant Muglikar and Pramod S. Sakhare
}

\begin{abstract}
Department of Veterinary Microbiology, Vanbandhu College of Veterinary Science and Animal Husbandry, Navsari Agricultural University, Navsari-396 450, Gujarat, India
\end{abstract}

*Corresponding author

\section{A B S T R A C T}

\begin{tabular}{|l|}
\hline Ke y w o r d s \\
BoHV-1, Bovine, \\
FAT, IBR \\
\hline Article Info \\
\hline $\begin{array}{l}\text { Accepted: } \\
15 \text { October } 2018 \\
\text { Available Online: } \\
10 \text { November } 2018\end{array}$ \\
\hline
\end{tabular}

\section{Introduction}

Bovine herpesvirus-1 (BoHV-1), a member of the subfamily Alphaherpesvirinae, is responsible for causing rhinotracheitis, pustular vulvovaginitis, abortion, mastitis, balanoposthitis, infertility, keratoconjunctivitis and encephalitis in bovines (Gibbs and Rweyemamu, 1977). In India, the infection was first reported by Mehrotra et al., (1976) and since then the disease has been prevalent and reported by many workers from various parts of the country (Samal et al., 1981; Renukaradhya et al., 1996; Trangadia et al., 2012; Krishnamoorthy et al., 2015). Currently, virus isolation, ELISA, PCR etc. are used for

\begin{abstract}
Detection of viral antigen by direct fluorescent antibody test (FAT) from clinical samples collected from cattle and buffaloes of Navsari, Surat and Valsad Districts of Southern Gujarat were carried out. Out of a total of 116 clinical samples (44-cattle, 72-buffaloes) tested, fluorescence was observed in $14(12.09 \%)$ samples. Species-wise, eight cattle $(11.11 \%)$ and 6 buffaloes (13.64\%) were found to be positive by the test. The highest number of animals were detected from Surat (14.29\%) followed by Valsad (12.07\%) and least in Navsari (10.81\%) district. Viral antigen detected in $8.00 \%(4 / 50), 7.14 \%(1 / 14)$, $28.57 \%(2 / 7)$ in cattle and $16.67 \%,(2 / 12), 16.67 \%(1 / 6), 11.547 \%(3 / 26)$ in buffaloes from nasal, conjunctival and vaginal swabs, respectively. Only placental cotyledon sample collected from cattle showed positive reaction by direct FAT.
\end{abstract}

the diagnosis of BoHV-1. The present study was designed to detect BoHV-1 virus in various clinical samples collected from bovine of Southern Gujarat by direct fluorescence antibody test (FAT).

\section{Materials and Methods}

\section{Collection of clinical samples}

A total of 116 clinical samples comprised of 72 samples (50 nasal swabs, 14 conjunctiva swabs, 07 vaginal swabs and one placental cotyledon from aborted case) from cattle and 44 from buffaloes (12 nasal swabs, 06 conjunctiva swabs and 26 vaginal swabs) were 
collected from Valsad, Navsari and Surat districts of Southern Gujarat for detection of BoHV-1 antigen by direct FAT. These samples were collected in viral transport media (VTM) made from Dulbecco's modified Eagles media (DMEM) with 2\% foetal calf serum (FCS) with kanamycin from animals exhibiting clinical signs such as conjunctivitis, lacrimation, serous/ mucopurulant nasal discharge, abortion and vulvo-vaginitis. Location-wise, species-wise and breed-wise details of sample collection are shown in Table 1.

\section{Direct FAT}

For standardization of test, infectious bovine rhinotracheitis (IBR) seed virus was procured from Veterinary Type Culture Collection (VTCC), National Research Centre on Equines (NRCE), Hisar (Haryana) under Material Transfer Agreement (MTA) and used as reference virus. Reference virus $(100 \mu \mathrm{l})$ was inoculated in $25 \mathrm{ml}$ tissue culture flask containing MDBK (Madin Derby Bovine Kidney) cell monolayer. The flask incubated at $37^{\circ} \mathrm{C}$ for 1 hour and $20 \mathrm{ml}$ of DMEM medium was added to it. Further the flask was incubated at $37^{\circ} \mathrm{C}$ for $24-36$ hours till $50 \%$ CPE (Cytopathic Effect) was observed. Then DMEM medium was discarded and MDBK cell monolayer was fixed in acetone-methanol (3:1) solution and further processed as per the test protocol and reagents supplied by VMRD Inc., Pullman, WA, USA. In brief, smears were prepared from $50 \mu 1$ of clinical samples on clean glass slide. These smears were air dried overnight at room temperature and fixed in acetone-methanol (3:1) at room temperature for 20 minutes. Then the slides were stained with $50-75 \mu \mathrm{l}$ of direct FA conjugate (Catalog no.: $210-69-\mathrm{IBR}$ ) for $30 \mathrm{~min}$ at $37^{\circ} \mathrm{C}$ in humid chamber. Further, the slides were gently rinsed in FA rinse buffer and soaked for $10 \mathrm{~min}$ in the same buffer. The slides were dried with paper towel without allowing stained surface to dry. Slides were mounted with FA Mounting Fluid and scanned with fluorescent microscope. Slides showed green fluorescence were considered as positive (Fig. 1c) While Figure $1 \mathrm{a}$ and $1 \mathrm{~b}$ indicate the negative and positive control, respectively.

\section{Results and Discussion}

Location-wise, species-wise and breed-wise incidence of BoHV-1 infection is depicted in Table 1. The highest incidence recorded in Surat $(14.29 \%)$ followed by Valsad $(12.07 \%)$ and Navsari $(10.81 \%)$ with an overall incidence of $12.09 \%$. Percent positivity in cattle and buffaloes were $11.11 \%$ and $13.64 \%$, respectively. Comparatively, higher incidence of BoHV-1 was observed in crossbred cattle $(11.54 \%)$ than Gir animals (10.00\%), whereas among buffaloes highest incidence observed in Mehsani (16.67\%) followed by Surti $(14.29 \%)$ and Jafarabadi $(9.09 \%)$ breed. Sample-wise incidence of BoHV-1 infection is depicted in Table 2.

Earlier workers (Rissi and Barros; 2013; Gould et al., 2013) used FAT as a diagnostic tool for detection of BoHV-1 viral antigen. In Gujarat, Jain (2006) and Jain et al., (2008) supported our findings and detected BoHV-1 antigen in $32.67 \%$ of semen samples of cattle and buffaloes by FAT. Further Jain et al., (2008b) recorded highest incidence of BoHV1 by direct FAT in Mehsani buffalo bulls (36.84\%) followed by Jafrabadi buffalo bulls (28.57\%) and Surti buffalo bulls (14.28\%).

In Odisha, Mishra et al., (1982) found an incidence of $18 \%$ by immunofluorescence technique. Misra and Mishra (1987) cultured 15 various tissues samples in primary bovine kidney cells and isolated BoHV-1 from 5 samples and confirmed by direct FAT. However, Elazhary et al., (1980) demonstrated BHV-1 in sperm heads from the bull by direct FAT. 
Table.1 Incidence of BoHV-1 antigen in bovine by direct FAT

\begin{tabular}{|c|c|c|c|}
\hline Attributes & Number tested & Number positive & Percent positive \\
\hline \multicolumn{4}{|c|}{ A) Location-wise } \\
\hline Valsad & 58 & 07 & 12.07 \\
\hline Navsari & 37 & 04 & 10.81 \\
\hline Surat & 21 & 03 & 14.29 \\
\hline Total & 116 & 14 & 12.09 \\
\hline \multicolumn{4}{|c|}{ Species-wise } \\
\hline Cattle & 72 & 08 & 11.11 \\
\hline Buffalo & 44 & 06 & 13.64 \\
\hline Total & 116 & 14 & 12.09 \\
\hline \multicolumn{4}{|c|}{ C) Breed-wise (Cattle) } \\
\hline Crossbred & 52 & 06 & 11.54 \\
\hline Gir & 20 & 02 & 10.00 \\
\hline Total & 72 & 08 & 11.11 \\
\hline \multicolumn{4}{|c|}{ D) $\quad$ Breed-wise (Buffalo) } \\
\hline Surti & 21 & 03 & 14.29 \\
\hline Mehsani & 12 & 02 & 16.67 \\
\hline Jafarabadi & 11 & 01 & 9.09 \\
\hline Total & 44 & 06 & 13.64 \\
\hline
\end{tabular}

Table.2 Sample-wise detection of BHV-1 antigen by direct FAT

\begin{tabular}{|c|c|c|c|c|c|c|c|}
\hline \multirow{3}{*}{$\begin{array}{l}\text { Sr. } \\
\text { No. }\end{array}$} & \multirow{3}{*}{$\begin{array}{l}\text { Type of } \\
\text { sample }\end{array}$} & \multicolumn{4}{|c|}{ Species of the animals } & \multicolumn{2}{|c|}{ Total } \\
\hline & & \multicolumn{2}{|c|}{ Cattle } & \multicolumn{2}{|c|}{ Buffaloes } & & \\
\hline & & Tested & Positive & Tested & Positive & Tested & Positive \\
\hline 01 & Nasal swabs & 50 & $\begin{array}{c}04 \\
(8.00)\end{array}$ & 12 & $\begin{array}{c}02 \\
(16.67)\end{array}$ & 62 & $06(9.68)$ \\
\hline 02 & $\begin{array}{l}\text { Conjunctival } \\
\text { swabs }\end{array}$ & 14 & $\begin{array}{c}01 \\
(7.14)\end{array}$ & 06 & 01(16.67) & 20 & $02(10.00)$ \\
\hline 03 & $\begin{array}{l}\text { Vaginal } \\
\text { swab }\end{array}$ & 07 & $\begin{array}{c}02 \\
(28.57)\end{array}$ & 26 & $\begin{array}{c}03 \\
(11.54)\end{array}$ & 33 & $\begin{array}{c}05 \\
(15.15)\end{array}$ \\
\hline 04 & $\begin{array}{l}\text { Placental } \\
\text { cotyledons }\end{array}$ & 01 & $01(100)$ & - & 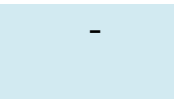 & 01 & $01(100)$ \\
\hline & Total & 72 & $\begin{array}{c}08 \\
(11.11)\end{array}$ & 44 & $\begin{array}{c}06 \\
(13.64)\end{array}$ & 116 & $\begin{array}{c}14 \\
(12.09)\end{array}$ \\
\hline
\end{tabular}

Note: Figures in parentheses indicate percentage. 
Fig.1a Normal uninfected MDBK cell monolayer as negative control at 36 hrs stained with direct FA conjugate viewed under fluorescent light microscope (100X)

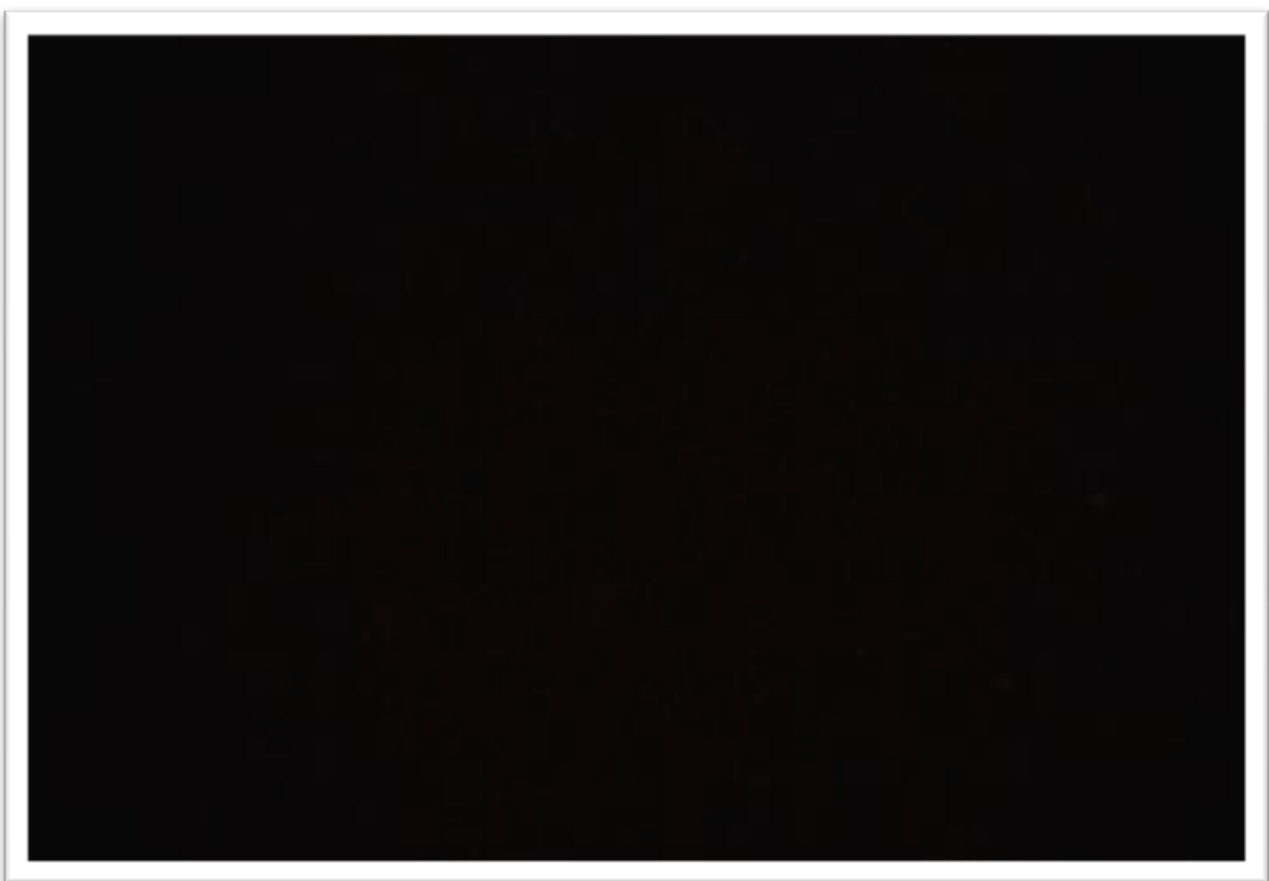

Note: The absence of fluorescence

Fig.1b BoHV-1 reference virus infected MDBK cell monolayer as positive control after 36 hrs stained with direct FA conjugate viewed under fluorescent light microscope (400X)

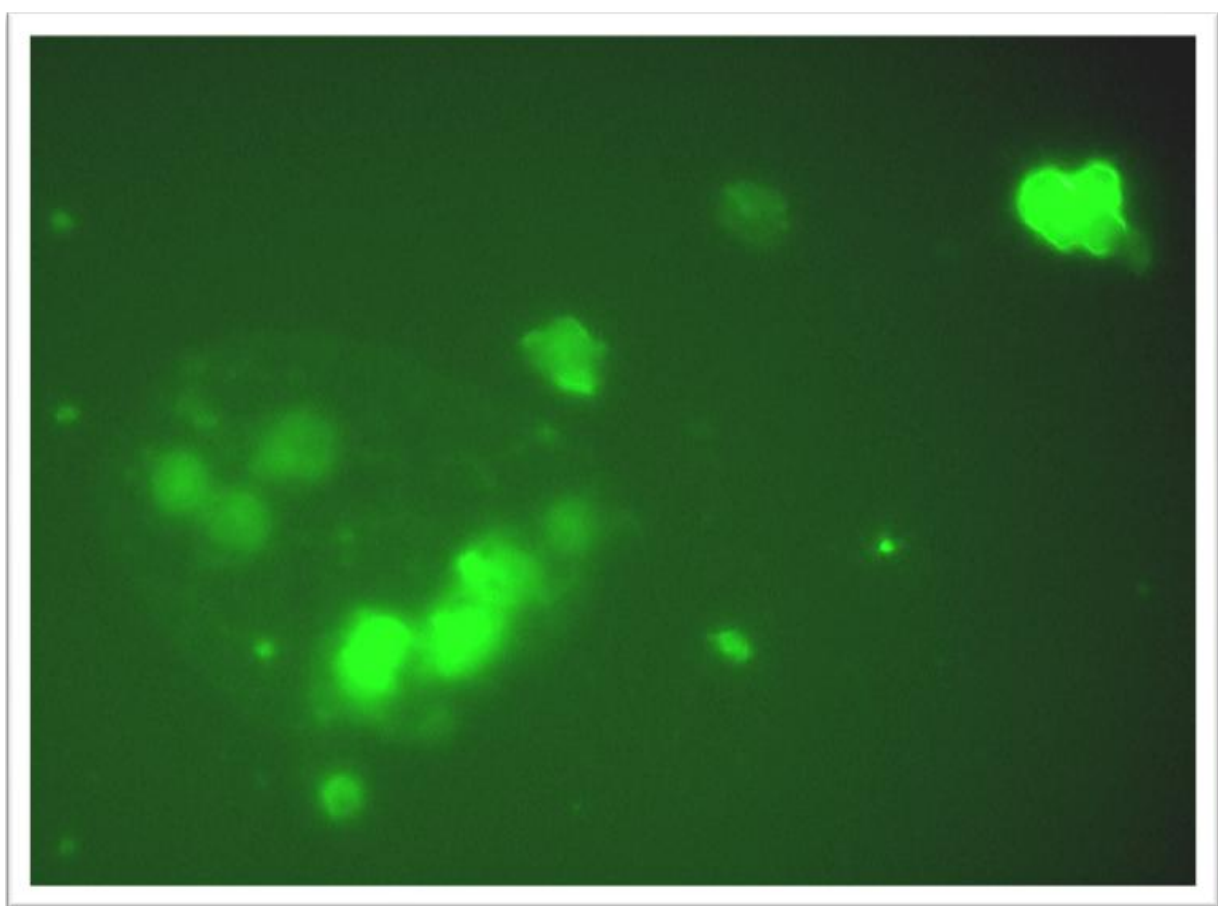

Note: The presence of fluorescence at the place previously CPE observed 
Fig.1c Immunofluorescent staining reaction with free BoHV-1 antigen cluster and direct FA conjugate in smear prepared from clinical sample

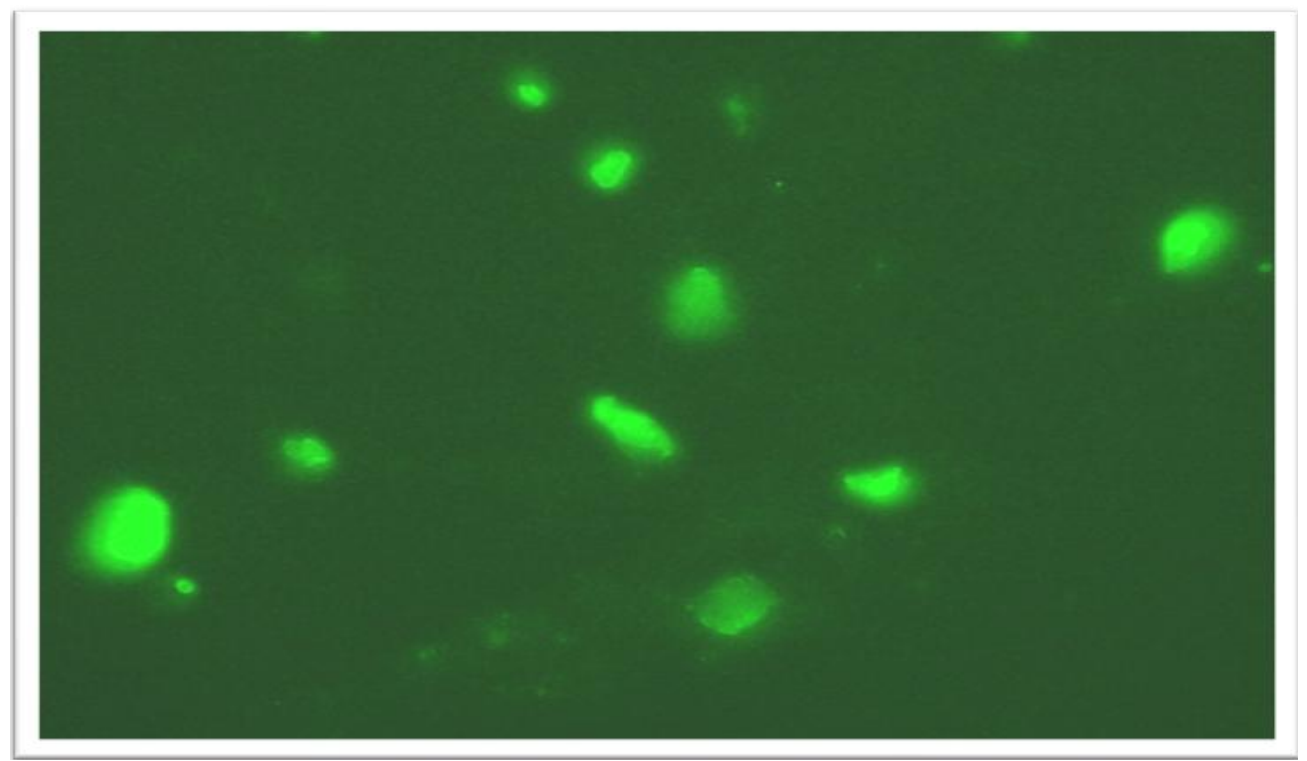

Note: The brightly fluorescing cluster of BoHV-1 (400X)

Due to the lack of published literature on detection of BHV-1 infection in semen samples using direct FAT, it is difficult to compare this study and to reach meaningful conclusions. However, it is deduced that the direct FAT can be a valuable test for detection of BoHV-1 antigen within a short period of time. Considering the fact that BoHV-1 can be transmitted through various routes, the findings of this study should be taken as an indicator of evidence of infection in the South Gujarat region of Gujarat. It warrants large scale systemic surveillance using appropriate sampling techniques to assist in planning of state level disease control programme.

\section{Acknowledgement}

The authors are thankful to Dr. N.H. Kelawala, the Dean, Navsari Veterinary College for providing all necessary facilities to conduct this study. Authors are also grateful to Dr. Navin Kumar, VTCC, NRCE, Hisar, Haryana for timely supply of BoHV-1 reference virus strain under MTA. Thanks are also due to NCCS, Pune, Maharashtra for supplying MDBK cell line. Authors are also thankful to the In-charge / veterinarians of veterinary dispensary, college clinic, panjarapoles and clinical camps of Surat, Navsari and Valsad districts for extending their help during sample collection.

\section{References}

Elazhary, M. A. S. Y., Lamothe, P., Silim, A. and Roy, R. S. 1980. Bovine herpesvirus type 1 in the sperm of a bull from a herd with fertility problems. Canadian Veterinary Journal. 21: 336339.

Gibbs and Rweyemamu (1977). Bovine herpesviruses. Part I, Commonwealth Bureau of Animal Health. Vet. Bull. 47: 317-343.

Gould, S., Cooper, V. L., Reichardt, N. and O' Connor, A. M. 2013. An evaluation of the prevalence of Bovine herpesvirus 1 abortions based on diagnostic submissions to five U.S.-based veterinary diagnostic laboratories. 
Journal of Veterinary Diagnostic Investigation 25: 243-247.

Jain, L. 2006. Detection of Bovine herpesvirus 1 (BHV-1) infection in breeding bulls by serological and molecular methods and its characterization by sequencing of PCR products. M.V.Sc. thesis submitted to A.A.U, Anand.

Jain, L., Kanani, A.N., Patel, T.J., Purohit, J.H., Jhala, M.K., Joshi, C.G., Chandel, B.S. and Chauhan, H.C. 2008. Detection of Bovine herpesvirus 1 (BHV-1) infection in semen of breeding bulls of Gujarat by A direct fluorescence. Buffalo Bulletin 27: 202206.

Krishnamoorthy, P., Patil, S. S., Shome R. and Rahman, H. 2015. Seroepidemiology of infectious bovine rhinotracheitis and brucellosis in organized dairy farms in southern India. Indian Journal of Animal Sciences 85: 695-700.

Mehrotra, M. L., Rajya, B. S. and Kumar, S. 1976. Infectious bovine rhinotracheitis (IBR) keratoconjunctivities in calves. Indian J. Vet. Path. 1: 70-73.

Mishra, P. K., Mishra, A., Tripathy, S. B., Parhi, N. K. and Nayak, B. C. 1982.
Detection of infectious bovine rhinotracheitis (IBR) virus in semen by immunofluorescence technique. Indian J. of Vet. Med. 2: 62-64.

Misra, P. K. and Mishra, A. 1987. Infectious bovine rhinotracheitis virus infection and infertility in cows, heifers and bulls. SO: Indian Journal of Animal Sciences. 57: 267-271.

Renukaradhya, G. J., Rajasekhar, M. and Raghavan, R. 1996. Prevalence of infectious bovine rhinotracheitis in Southern India. Rev. Sci. Tech. Off. Int. Epiz. 15: 1021-1028.

Rissi, D. R. and Barros, C. S. L. 2013. Necrotizing meningoencephalitis in a cow. Veterinary Pathology 50: 926-929.

Samal, S. K., Mallick, B. B. and Das, S. K. 1981. Note on the incidence of IBR virus infection among cattle in India. Indian J. Anim. Sci. 51: 895-897.

Trangadia, B.J., Rana, S.K., Nagmani, K. and Srinivasan, V.A. 2012. Serological Investigation of Bovine Brucellosis, Johne's Disease and Infectious Bovine Rhinotracheitis in Two States of India. Journal of Advanced Veterinary Research, 2: 38-41.

\section{How to cite this article:}

Dharmesh R. Patel, Irsadullakhan H. Kalyani, Bhavesh J. Trangadia, Kishan K. Sharma, Pushpa M. Makwana, Dhruv Desai, Dushyant Muglikar and Pramod S. Sakhare. 2018. Detection of Bovine Herpesvirus-1 Infection in Bovine Clinical Samples by Direct Fluorescent Antibody Test. Int.J.Curr.Microbiol.App.Sci. 7(11): 2229-2234. doi: https://doi.org/10.20546/ijcmas.2018.711.249 